\title{
SUBSTANTIATION AND FEATURES OF EVALUATING THE ECONOMIC EFFICIENCY OF INNOVATION
}

\section{ОБГРУНТУВАННЯ ТА ОСОБЛИВОСТІ ОЦІНЮВАННЯ ЕКОНОМІЧНОЇ ЕФЕКТИВНОСТІ ІННОВАЦІЇ}

\section{Iryna Chernyavs'ka ${ }^{1}$}

DOI: https://doi.org/10.30525/978-9934-588-38-9-36

Abstract. Modern transformations in the economy of Ukraine require enterprises to continuously innovate. Innovation development is one of the key ways of maintaining high rates of enterprise development and represents research work of forecasting-analytical and technical-economic character, as a rule, associated with the management and implementation of an innovative project. These issues determine the need for a theoretical and practical solution to the issues of effective management of innovation activities, analysis of the enterprise's readiness to develop and implement innovation, assessing the economic efficiency of innovation, etc. In this regard, there is an objective need to justify the stages of development of innovation project concept and the essence of certain aspects of project analysis, improving the technique of estimation the effectiveness of different types of innovation.

The subject of the study is theoretical and methodological aspects of the effectiveness estimation of innovations and innovative projects.

The basis for the analysis was the scientific works of domestic scientists on these issues. Theoretical and methodological basis of the work is a set of principles and methods of scientific research: the principles of system analysis, systematization and theoretical generalization, methods of comparative analysis, structural and functional analysis, system-dynamic approach.

The purpose of the study is to improve theoretical foundations and formalize methodological approaches to assess the economic efficiency of innovation.

The problem of development of methodology of estimation of economic efficiency of innovations and innovative projects is actualized in

\footnotetext{
${ }^{1} \mathrm{PhD}$ (Economics), Associate Professor, Associate Professor at Department of Economics and Industry Engineering, Dniprovsky State Technical University, Ukraine

(C) Iryna Chernyavs'ka
} 
the research. Theoretical aspects of the concept of innovative project were analyzed and the choice of stages of its development was grounded, typologization of aspects of project analysis is investigated and grounded. It was proved that the tools and methodology for the effectiveness estimation of innovation depends on the content of the project, objects of innovation, etc. The study shows that the estimation of innovation performance should be based on the calculation of the criteria for the effectiveness of the investment project, as well as a comparison of the effect of innovation and the cost of their development, production and consumption.

The paper proposes a block diagram and formalizes methodological approaches for estimation of innovation efficiency. The implementation of the methodological approaches proposed in this study can have a useful effect that will help to optimize the level of costs for innovation development, production and consumption.

\section{1. Вступ}

Сучасні трансформації в економіці України вимагають від підприємств безперервного впровадження інновацій. Розробка інновацій є одним 3 ключових способів підтримки високих темпів розвитку підприємства й являє собою особливим чином організовану науково-дослідну роботу прогнозно-аналітичного і техніко-економічного характеру, пов'язану, як правило, з постановкою мети розробки інноваційного проєкту, розробкою його концепції, плануванням i оформленням проєктно-кошторисної документації. Концепція інноваційного проєкту повинна визначати варіанти його реалізації, формувати основні цілі й очікувані кінцеві результати, оцінювати конкурентоспроможність і перспективність результатів проєкту, а також оцінювати можливу ефективність. Проблемам розробки методології оцінювання ефективності та інноваційної привабливості присвячені до-слідження В. Гейця, В. Ляшенко, І. Топалової, Б. Шелегеди [1-4].

У своїх наукових працях вони доводили, що економічне оцінювання ефективності інновацій можливо на основі порівняння ключових параметрів інноваційної діяльності підприємств, які реалізують інноваційні проєкти, із середніми значеннями у розрізі сфер економічної діяльності. Відповідно з цим вони пропонували підходи щодо визначення динаміки здійснення інноваційної діяльності. Завдяки їхнім розробкам набули 
розвитку питання оцінювання ефективності інноваційного проєкту, вимірювання ефективності інноваційної діяльності окремого підприємства та їх груп за видами економічної діяльності.

Аналіз публікацій зазначених авторів дозволяє стверджувати, що існує потреба в комплексному вивченні проблем управління інноваційною діяльністю та інноваційними проєктами. Недостатньо висвітленими є питання, пов'язані з оцінюванням ефективності різних типів інновацій. Зазначена проблематика визначає необхідність теоретичного й практичного вирішення питань ефективного управління інноваційною діяльністю, аналізу готовності підприємства до розробки й впровадження інновації, оцінювання економічної ефективності інновації тощо. У зв'язку з цим виникає об'єктивна необхідність в обгрунтуванні етапів розробки концепції інноваційного проєкту та сутності окремих аспектів проєктного аналізу, удосконаленням методики оцінювання ефективності різних типів інновацій.

Предметом дослідження є теоретико-методологічні аспекти оцінювання ефективності інноваційної діяльності та інноваційних проєктів. Базою для аналізу слугували наукові праці вітчизняних вчених щодо зазначеної проблематики.

Метою дослідження є удосконалення теоретичних засад та формалізація методичних підходів щодо оцінювання економічної ефективності інновацій, реалізація яких дозволить оптимізувати рівень витрат на їх розроблення, виробництво та споживання.

Теоретико-методологічною основою роботи є сукупність принципів і методів наукового дослідження: принципи системного аналізу, систематизації і теоретичного узагальнення, методи порівняльного аналізу, структурно-функціонального аналізу, системно-динамічний підхід.

\section{2. Теоретичні засади формування концепції інноваційного проєкту в межах просктного аналізу}

У процесі розробки концепції інноваційного проєкту виділяють такі етапи: формування інноваційної ідеї і постановка мети; маркетингові дослідження ідеї; структуризація проєкту; аналіз ризику і невизначеності; вибір варіанта реалізації проєкту [5]. Погоджуючись 3 таким переліком етапів, пропонується обгрунтування кожного з них. 
Формування інноващійної ідеї $і$ постановка мети. Виникнення інноваційної ідеї є відправною точкою, з якої починається розробка інновації. Формування інноваційної ідеї розглядається з двох позицій. 3 одного боку, інноваційна ідея становить основу, суть інноваційного проєкту, що знаходить відображення в постановці генеральної (кінцевої) мети проєкту (ідея створення нового продукту чи послуги, ідея організаційних перетворень у галузі, регіоні, на діючому підприємстві тощо).

У той же час, під формуванням інноваційної ідеї (задуму) розуміється задуманий план дій, тобто способи чи шляхи досягнення мети проєкту. Уже на цьому етапі визначаються альтернативні варіанти вирішення проблеми. Ідея може виникнути спонтанно чи стати результатом тривалого процесу, вона може бути результатом «колективної експертизи» чи індивідуального аналізу [6].

До методів генерування і формування інноваційної ідеї відносяться на-ступні інтуїтивні методи: виявлення думок (метод інтерв'ю), анкетування (вибіркових опитувань), написання сценарію, «мозкову атаку», морфологічний аналіз тощо.

Маркетингові дослідження ідеї. Паралельно з формуванням інноваційної ідеї проєкту проводяться іiі маркетингові дослідження. Метою цього етапу є визначення сфери впливу проєкту на економічний розвиток i, як наслідок, кількісне уточнення мети проєкту і завдань за окремими періодами. Кінцеві цілі й завдання інноваційного проєкту не завжди можуть бути встановлені у вигляді конкретних кількісних показників на стадії вибору й обгрунтування проблеми (інноваційної ідеї). Тому власне розробка проєкту повинна починатися з кількісного уточнення кінцевої мети проєкту і встановлення проміжних завдань іiі реалізації за окремими тимчасовими періодами для різних варіантів реалізації. 3 цією метою: встановлюються можливі споживачі цільового продукту проєкту; аналізуються можливості й економічна доцільність заміни виробленої продукції новими видами цільової продукції; вивчається структура галузей, що забезпечують реалізацію проєкту сировиною, енергоресурсами, комплектуючими ви робами тощо; аналізуються нові сфери використання кінцевого продукту проєкту; досліджуються економічні і соціальні наслідки реалізації проєкту [7].

На етапі маркетингових досліджень повинні використовуватися загальні методи маркетингу інновацій. Результати маркетингових 
досліджень виражаються в конкретних кількісних значеннях цільових параметрів проєкту.

Структуризація інноваційного проєкту. Встановлені на попередніх ета-пах цільові параметри проєкту є основою для формування переліку проектних заходів щодо досягнення кінцевої мети проєкту. Для визначення складу необхідних заходів кінцеві цілі попередньо структуруються, тобто розбиваються на складові елементи. Практика показує, що в структуризації проєкту необхідно розрізняти два різновиди: функціональну і проблемну.

Функціональна структуризація проєкту. При структуризації інновацій-ного проєкту спочатку встановлюється склад функціональних елементів, що $є$ умовою повного і комплексного його вирішення. Інструментом такої функціональної структуризації проблеми при розробці проєкту слугує «дерево цілей», побудова якого базується не на формальних залежностях, а на використанні переважно експертних оцінок фахівців. За кожним з установлених елементів, включаючи й альтернативні, визначається обмежений перелік найважливіших цільових показників, що характеризує їхній науково-технічний рівень і розкриває зміст цільових показників елементів вищестоящого рівня.

При визначенні значень цільових показників варто виходити 3 необхідності обов'язкового забезпечення цільових параметрів відповідного елемента рівня, що знаходиться вище. Розрахунок цільових параметрів за елементами «дерева цілей» здійснюється послідовним розукрупненням від вищого рівня до нижчого. Крім цільових показників, за кожним з елементів «дерева цілей» рекомендується встановлювати обмежувальні параметри, які встановлюють ті вимоги, що обов'язково повинні бути витримані при реалізації проєкту. Необхідно враховувати, що обмежувальні параметри, які є умовами досягнення цільових показників, різко скорочують кількість можливих шляхів вирішення проблеми. Таким чином, встановлення складу обмежувальних параметрів проєкту й їхніх якісних значень може розглядатися як перша і найбільша стадія техніко-економічного обгрунтування варіанта реалізації проєкту.

Проблемна структуризація проєкту. Побудоване «дерево цілей» переформулюється потім у проблемновиражену систему завдань i заходів - «дерево робіт». Якщо «дерево цілей» встановлює необхідні 
засоби досягнення цілей проєкту, то комплекс заходів («дерево робіт») повинен визначати шляхи і способи одержання встановлених засобів. При формуванні заходів повинен використовуватися композиційний принцип послідовного агрегування робіт нижчого рівня в теми, завдання, проблеми вищого рівня. Виходячи з цих позицій пропонується така послідовність здійснення необхідних заходів: вивчається можливість і доцільність забезпечення цільових параметрів за рахунок розширення обсягів виробництва традиційної техніки; формулюються заходи щодо освоєння у виробництві результатів науково-дослідних робіт; при недостатності наукового заділу вивчається можливість щодо використання досвіду іноземних країн на основі придбання ліцензій, технологій, уречевлених технологій.

Сукупність робіт, встановлених за елементами нижчого рівня «дерева цілей», поєднується на наступних стадіях розробки проєкту в теми, завдання й етапи, пов'язані зі створенням відповідних елементів вищого рівня. Одержуване в такий спосіб «дерево робіт» являє собою один 3 можливих варіантів реалізації проєкту. Будь-який з варіантів, здатний реалізувати мету проєкту, варто розглядати як допустимий. У межах установлених обмежувальних параметрів проєкту допустимі варіанти його реалізації можуть розрізнятися технологічними способами виробництва продукту чи пропорціями в розподілі виробництва його за технологічними способами, видами використовуваних сировини і матеріалів, якісними характеристиками цільового продукту, прийнятими способами задоволення потреби в ньому, складом заходів.

Результатом структуризації проєкту є перелік заходів, виконання яких необхідне для забезпечення досягнення у встановлений термін цільових зна-чень проєкту за кожним з варіантів його реалізації.

Аналіз ризику $і$ невизначеності. Фактори ризику і невизначеності підля-гають обліку в розрахунках ефективності, якщо за різних можливих умов реалізації витрати і результати за проєктом різні. При оцінюванні проєктів найбільш істотними відібрано такі види невизначеності й інвестиційних ризиків: ризик, пов'язаний з нестабільністю законодавства і поточної економічної ситуації, умов інвестування і використання прибутку; зовнішньоекономічний ризик; невизначеність політичної ситуації, ризик несприятливих соціально-політичних змін у країні чи регіоні; неповнота чи неточність інформації про динаміку 
техніко-економічних показників, параметри нової техніки і технології; коливання ринкової кон'юнктури, цін, валютних курсів тощо; виробничо-технологічний ризик; невизначеність інтересів, неповнота чи неточність інформації про фінансове становище і ділову репутацію стейкхолдерів.

Конщепція проєктного аналізу. Життєздатність інноваційного проєкту оцінюється шляхом проведення проєктного аналізу. Як правило, аналіз проєктів включає спеціальні розділи, в яких здійснюється оцінка комерційної, технічної, інституціональної, соціальної, екологічної, фінансової та економічної реалізації проєкту. Ці аспекти детально вивчаються на фазі ініціалізації та відслідковуються протягом всього періоду його життєвого циклу [8]. Пропонується обгрунтування сутності кожного аспекту.

Комериійний аналіз. Метою комерційного аналізу інноваційного проєкту є оцінка інвестиції з погляду перспектив кінцевого ринку для продукції чи послуг. Завданнями комерційного аналізу є: характеристика ринку; визначення та обгрунтування ціни реалізації продукції; розробка заходів 3 управління маркетингом 3 метою виведення продукції чи технології на ринок, розрахунок вартості цих заходів. Основними компонентами оцінки інноваційної продукції (технології) визначено такі: опис інноваційної продукції та аналіз іiї технічного рівня; визначення потенційного ринку технології; оцінка впливу зовнішнього маркетингового середовища, в тому числі впливу політики уряду держави щодо комерційного використання інноваційної продукції; аналіз комерційного потенціалу інноваційної продукції; розробка моделі комерціалізації інноваційної продукції для внутрішнього та світового ринків; аналіз зроблених кроків комерціалізації (спроби ліцензування, переговори з потенційними партнерами чи інвесторами); підготовка резюме проекту; написання бізнес-плану чи концепції бізнесу.

Опис інноваційної продукції (технології) можна виконати у трьох рівнях:

- стисле викладення обсягом однієї сторінки, що відповідає частині ре-зюме бізнес-плану, мовою, яка є зрозумілою для непрофесіонала в технічній сфері;

- детальний опис технології зрозумілою для непрофесіоналів мовою 3 великою кількістю таблиць, які порівнюють усі параметри 
запропонованої технології (продукції) з параметрами існуючої на ринку, конкурентом або із запитами споживачів, якщо продукція $\epsilon$ абсолютно новою для ринку;

- додатки, що дозволяють професіоналам в цій сфері детально проаналізувати технологію. Дані, які є комерційними, науковими таємницями, не можуть бути включені до опису, але можуть бути використаними для аналізу технології після укладання відповідного договору про конфіденційність.

Зауважимо на важливому питанні, а саме на способі демонстрації продукції чи технології потенційним споживачам, партнерам, інвесторам. Тут справедливе правило, що «краще один раз побачити, ніж сто разів почути». Але тут є багато проблем та небезпек. Наприклад, якщо продукція (технологія) уже існує у вигляді прототипу й іiі можна віддати для будь-якого випробування, то виникає питання, згідно яких договорів (скажімо, опціонних), які зусилля потрібно зробити для збереження секретів, чи можна довірити експонат партнерам, інвесторам.

Вибір потенційного ринку технологій є дуже важливим для прийняття рішення про можливість пошуку стратегічного партнера чи інвестора. При самій досконалій технології іiі буде дуже складно розвивати, якщо ринок споживачів цієї технології є незначний. Робота на кожному ринку потребує різних знань і навичок, як і аналіз кожного з цих ринків потребує своїх методів, які відрізняються за складністю, часом та фінансовими витратами. Кожен ринок необхідно проаналізувати не тільки з точки зору його сьогоднішнього стану. Потрібно проаналізувати перспективи його змін в часі й місцезнаходження, вплив на нього змін в політиці, керівництві тощо. Залежно від розміру ринку потрібно розробити маркетинговий план для комерціалізації технології.

Розвиток і комерціалізація технології відбуваються при змінних факторах внутрішнього та зовнішнього середовища. Внутрішнім середовищем можна керувати, а вплив зовнішнього середовища можна тільки враховувати. Для успішної комерціалізації технології дуже важливим є розуміння ролі держави. В рамках цього етапу проекту слід проаналізувати:

- як держава підтримує і фінансує розробки тієї сфери знань, в якій розроблена технологія, які організації ведуть дослідження в даній сфері, як це може вплинути на комерціалізацію розробленої технології; 
- як політика уряду в сфері комерціалізації технології та підтримки науки і техніки сприяє чи перешкоджає комерціалізації розробленої технології і якими засобами можна скористатися для прискорення комерціалізації технології;

- як політика держави впливає на комерціалізацію технології на міжнародному ринку;

- вплив найбільш важливих факторів державної політики на процес ко-мерціалізації технології;

- вплив інших основних факторів зовнішнього маркетингового середо-вища на процес комерціалізації технології.

Для оцінки впливу зовнішнього середовища на комерціалізацію технології необхідно провести оцінку стійкості проєкту до змін зовнішнього середовища. Після аналізу технічного рівня технології, аналізу ринку і умов реалізації технології необхідно проаналізувати комерційний потенціал технології. Це дуже важливий елемент роботи, тому що після такого аналізу можливо необхідно буде припинити роботу.

Щоб зробити висновок про комерційний потенціал технології, необхідно розглянути зроблені раніше оцінки ризику і конкурентоспроможності технології за технічними параметрами.

Аналіз комерційного потенціалу проєкту є прямим продовженням стану оцінки ринку. Вийти на ринок часто заважають рішення керівництва різних країн, правила експорту та імпорту сировини, комплектуючих, капіталів і робочої сили, митні та торгові правила, культурні традиції й звички. Необхідно довести, що ринок, який проаналізовано, є доступним.

Важливим питанням аналізу комерційного потенціалу технології $€$ опис ключових переваг технології (продукції), завдяки яким іiї будуть купувати.

Наступним важливим питанням є вибір необхідних ресурсів для реалізації даного проєкту. Фінансова частина цього аналізу - аналіз грошових потоків, стійкості проєкту. Дуже часто розробники технології погано розуміють перешкоди, які пов'язані з просуванням технології на ринок, і це часто суттєво перевищує витрати на розробку технології. Зазначені питання потрібують особливої уваги в фінансовому аналізі. Крім фінансових ресурсів слід проаналізувати склад команди і запропонувати вирішення питання формування основних напрямків діяльності - розробка, фінансування, маркетинг, спільний менеджмент. 
Завершальним елементом оцінки повинні стати висновки про доцільність чи недоцільність комерціалізації.

Технічний аналіз інноваційних проєктів має на меті вивчення техніко-технологічних альтернатив, варіантів місця розташування виробництва, термінів реалізації проєкту і його фаз, графіків проєкту, визначення доступності й достатності джерел сировини та інших споживаних ресурсів. Всі ці питання вивчаються на стадії передінвестиційного дослідження при розробці короткого техніко-економічного обгрунтування, повного техніко-економічного обгрунтування, при розробці робочої документації.

Інституціональний аналіз інноваційних проєктів має на меті оцінку організаційного, правового, політичного й адміністративного оточення, у рамках якого передбачається здійснити проєкт. Інституціональний аналіз покликаний дати відповіді на питання організаційного характеру і розробити рекомендації щодо: розробки або використання тих чи інших методів і засобів менеджменту, у тому числі моніторингу й оцінки проєкту; розробки організаційної структури проєкту та можливі зміни в ній; планування розміщення інвестицій; комплектування і навчання персоналу; організації фінансової діяльності, у тому числі управління фінансами, розробка кошторисів; організації матеріально-технічного забезпечення проєктів; розробки систем експлуатації i технічного обслуговування проєкту та його продукту (результату, послуги); міжорганізаційної координації та кооперації.

Соціальний аналіз. Метою соціального аналізу є визначення прийнятності варіантів реалізації проєкту з погляду користувачів, населення регіону, де здійснюється проєкт, розробка стратегії реалізації проєкту, що дає змогу здобути підтримку населення, досягти цілей проєкту та поліпшити характеристики його соціального середовища. Підготовка соціальних аспектів проєкту потребує розробки заходів стимулювання позитивних змін у соціальному середовищі проєкту. Всебічний підхід до оцінки проєкту передбачає визначення впливу проєкту на людей, що беруть у ньому участь, користуються його результатами, одержують відповідні вигоди, на виробників, постачальників та інших учасників проекту. Доволі часто нехтування соціальних аспектів проєкту призводить до невдач, оскільки він заходить у суперечність з традиційними цінностями, не бере до уваги соціальну організацію людей, їх мотивацію до реалізації проєкту. 
До основних соціальних результатів проєкту, які необхідно відобразити в економічній оцінці, належать: зміна кількості робочих місць у регіоні; поліпшення житлових та культурно-побутових умов працівників; зміна структури виробничого персоналу; зміна рівня здоров'я населення.

Екологічний аналіз. Екологічний аналіз посідає особливе місце. Це місце зумовлене двома причинами: 1) недостатньою вивченістю взаємовідношення між діяльністю людини та довкіллям; 2) багато екологічних рішень, що ухвалюються, призводять до незворотних змін у природі. Метою екологічного аналізу інноваційного проєкту є виключення потенційної шкоди довколишньому середовищу під час здійснення та експлуатації проєкту і визначення заходів, необхідних для іiі пом'якшення або запобігання їй. Основними принципами проведення екологічного аналізу є наступні: оцінка очевидних екологічних наслідків проєкту; урахування взаємозалежності вигід та витрат; оцінка екологічних вигід та витрат у рамках підходу «з проєктом» і «без проєкту»; використання механізму оцінки неявних вигід і витрат; оцінка змін продуктивності; аналіз ефективності витрат.

Фінансовий та економічний аналіз. Здійснюючи фінансовий аналіз, про-єкт вивчають з погляду фінансової і комерційної привабливості для інвестора та організацій, які його реалізують. Тому всі витрати й доходи, одержані в результаті здійснення проєкту, мають явний характер і фінансову відчутність. Критеріями відбору інноваційних проєктів за результатами фінансового аналізу є додаткові грошові потоки, що виникають при реалізації, його рентабельність та окупність вкладеного капіталу. Оцінка інноваційного проєкту заснована на узгодженості його цілей з корпоративними цілями розвитку, які не завжди збігаються $з$ національними інтересами.

Аналіз економічних аспектів покликаний визначити, чи сприяє даний проєкт здійсненню цілей розвитку національної економіки, а також чи існують альтернативні шляхи досягнення тих самих економічних вигід меншими витратами. Економічний аналіз має на меті оцінити відповідність проєкту його економічному середовищу, що регламентує розподіл доходів, обмеження або стимулювання виробництва й торгівлі тощо, i безпосередньо впливає на фінансову здійснюваність проєкту.

Цілі економічного аналізу вимагають абсолютно іншого аналітичного підходу. Базовою концепцією економічного аналізу є концеп- 
ція альтернативної вартості, яка засвідчує, що, оскільки всі ресурси суспільства обмежені й можуть мати різне застосування, їх вартість повинна вимірюватися з погляду втраченої можливості займатися найкращим з доступних альтернативних видів діяльності, які вимагають використання тих самих ресурсів.

Метою економічного аналізу інноваційного проєкту є встановлення його національної привабливості, оцінка його економічної ефективності на підставі альтернативної вартості ресурсів, які використовуються у проєкті, і продукції проєкту та визначення можливості сприяння проєкту національному добробуту країни. Під час проведення економічного аналізу належить коригувати фінансові показники, які значною мірою викривляють реальну вартість товарів. Для цього необхідно уникнути впливу трансфертних платежів на формування вартості ресурсів проєкту.

Дослідження впливу інноваційного проєкту на економіку країни має су-проводжуватися визначенням побічних ефектів проекту та їх наслідків. Аналітики повинні простежити й виміряти тільки найважливіші зовнішні ефекти, оскільки оцінити всі побічні ефекти проекту практично неможливо, та й недоцільно. Реалізація інноваційного проекту може сприяти зниженню цін на споживчі товари та послуги, ліквідації дефіциту будь-якого товару, розвитку інфраструктури районів, створенню додаткових робочих місць тощо. Такі економічні результати повинні враховуватися при оцінці економічної ефективності проєкту.

\section{3. Методологічні аспекти оцінювання ефективності інновацій}

Обгрунтування та інструментарій оцінювання ефективності інновацій залежить від змісту проєкту, який може мати експериментально-дослідницьке, технологічне, конструкторське спрямування, напрямок моделювання тощо. Структурна схема оцінювання ефективності інновації представлена на рис. 1 .

Аналіз та економічне обгрунтування $є$ заключним етапом розробки або вдосконалення новацій та оригінальних технічних рішень, які можуть бути впроваджені у реальний виробничий процес. Проведення аналізу та економічного обгрунтування передбачає проходження наступних етапів:

- обгрунтування вибору об'єкту дослідження, постановка мети та завдань аналізу; 


\section{Chapter «Economic sciences»}

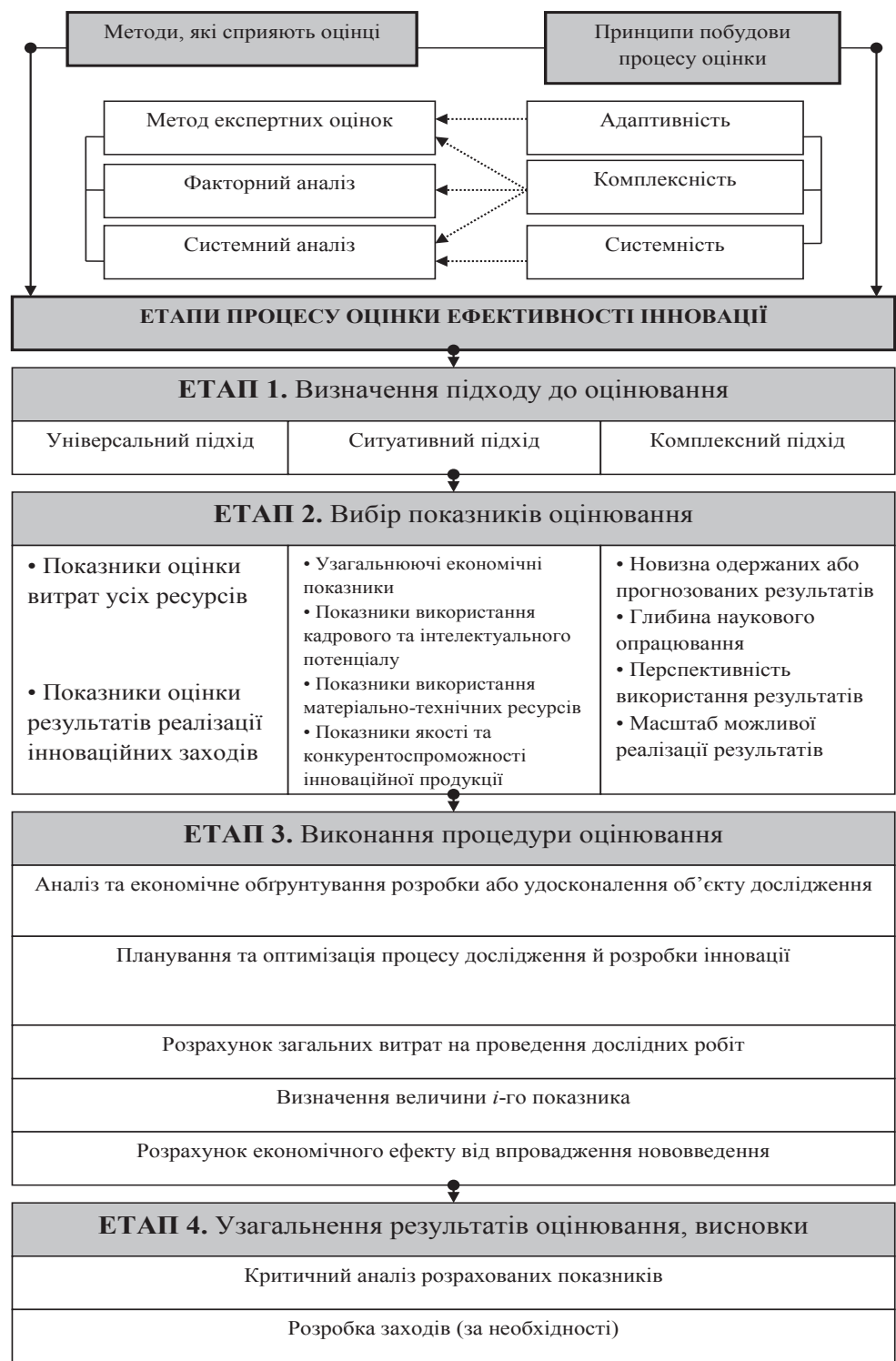

Рис. 1. Структурна схема оцінювання ефективності інновації 
- збір та обробка необхідної похідної інформації;

- вибір системи показників, за допомогою яких визначається економічний ефект від здійснення інновацій;

- обгрунтування економічної (соціальної, екологічної тощо) значущості розробки.

Вибір методу оцінювання ефективності інновацій залежить від об'єктів, якими можуть бути різні типи інновацій:

- основні засоби (нові, реконструйовані, модернізовані);

- оборотні засоби (сировина, паливо, матеріали, енергія);

- предмети кінцевого споживання (готова продукція, роботи, послуги);

- технологічні процеси (нові, удосконалені);

- методи організації виробництва, праці та управління (інноваційний менеджмент);

- інноваційний проєкт (обгрунтування можливості повернення інвестиційних витрат).

Загальним принципом оцінювання економічної ефективності інновацій $є$ порівняння ефекту від застосування нововведень і витрат на їх розроблення, виробництво та споживання [2; 8]. Згідно об'єкту дослідження оцінку ефективності рекомендується проводити за одним з нижченаведених принципів.

Принции оцінювання - розрахунок критеріїв ефективності інвестиційного проєкту.

Для реалізації проєктних рішень необхідно визначити обсяг інвестицій, необхідний для їх здійснення. Величина інвестицій дорівнює загальній сумі основних засобів, оборотних засобів, нематеріальних активів, витрат на проведення дослідних робіт. Ефективність інноваційного проєкту визначається величиною прибутку, отриманого за рахунок реалізації інновації протягом життєвого циклу проєкту (терміну відтворення). При цьому обов'язково слід ураховувати зміну вартості грошей у часі (дисконтування).

Річна сума очікуваного прибутку від реалізації проєкту розраховується за формулою:

$$
P_{t}=\left(P_{r}-C_{s t}\right) \cdot Q,
$$

де $P_{r}$ - прогноз ціни одиниці продукції з урахуванням галузевої рентабельності, грн.; $C_{s t}$ - собівартість одиниці продукції, грн.; $Q$ прогноз річного проєктного обсягу виробництва продукції, од. 
Річна сума очікуваного чистого прибутку від реалізації проєкту розраховується за формулою:

$$
P_{t(n)}=P_{t}-P_{t} \cdot P_{t a x},
$$

де $P_{t a x}$ - розмір ставки податку на прибуток, част. од. [9].

Очікуваний грошовий потік $t$-го року розраховується за формулою:

$$
C F_{t}=P_{t(n)}+A_{t},
$$

де $P_{t(n)}$ - очікуваний чистий прибуток підприємства у $t$-му році $(t=1,2,3 \ldots n)$, грн.; $t$ - число періодів часу, за який нараховується прибуток; $A_{t}$ - величина амортизаційних відрахувань $t$-го року, грн.

Річну суму амортизаційних відрахувань можна визначити прямолінійним методом за формулою [10]:

$$
A_{t}=B_{I V} \cdot H_{c}
$$

де $B_{I V}-$ первісна вартість об'єкта основних засобів, грн.; $H_{c}-$ норма амортизації, част. од., що розраховується за формулою:

$$
H_{c}=\frac{B_{I V}-B_{L V}}{B_{I V} \cdot T_{\text {use }}},
$$

де $B_{L V}$ - ліквідаційна вартість об'єкта основних засобів, грн.; $T_{\text {use }}-$ термін корисного використання об'єкта основних засобів, років.

Загальний абсолютний ефект від реалізації проєкту характеризує чиста теперішня (дисконтована) вартість, що розраховується за формулою:

$$
N P V=\sum_{t=1}^{n_{2}} \frac{C F_{t}}{(1+r)^{t}}-\sum_{j=0}^{n_{1}} \frac{I C_{j}}{(1+r)^{j}},
$$

де $C F_{t}$ - грошовий потік t-го року, грн.; $I C_{j}-$ інвестиції в $j$-ому році, грн.; $r$ - дисконтна ставка (нормативна), част. од.;

Рішення доцільно впроваджувати, якщо чиста теперішня вартість $€$ позитивною. Показник чистої теперішньої вартості може використовуватися в якості єдиного самостійного індикатора прибутковості інноваційного проєкту.

Для здійснення порівняльної оцінки кількох альтернативних проєктів доцільно використовувати показник індексу рентабельності, який розраховується за формулою:

$$
P I=\sum_{t=1}^{n_{2}} \frac{C F_{t}}{(1+r)^{t}}: \sum_{j=0}^{n_{1}} \frac{I C_{j}}{(1+r)^{j}} .
$$


Перевагу слід надавати тому проєкту, для якого індекс рентабельності є найвищим.

Внутрішня норма рентабельності дає змогу зробити висновок про існуючий резерв «безпеки проєкту», а саме показує ту норму дисконту $I R R$, за якої величина дисконтованих доходів за відтворювальний період стає рівною розміру інвестицій, які вкладені у реалізацію інноваційного проєкту. Тобто внутрішня норма рентабельності (доходності) знаходиться із рівняння:

$$
\sum_{i=1}^{n_{2}} \frac{C F_{t}}{(1+I R R)^{t}}-\sum_{j=0}^{n_{1}} \frac{I C_{j}}{(1+I R R)^{j}}=0 .
$$

Якщо величина внутрішньої норми рентабельності проєкту більше за нормативну ставку дисконту, і більше за $I R R$ альтернативних варіантів проєкту, то рішення про реалізацію проєкту може бути позитивним.

Період, протягом якого прибуток, отриманий внаслідок реалізації інноваційного проєкту, забезпечить повернення вкладених інвестицій, характеризує термін окупності інноваційного проєкту. Його розрахунок базується на дисконтованому грошовому потоці або у інших спосіб, за якого до розрахунку приймаються недисконтовані грошові потоки.

Дисконтований період окупності інноваційного проєкту розраховується за формулою:

$$
D P P=\frac{I C}{\overline{C F_{n p}}},
$$

де $I C$ - первісні інвестиції в проєкт, грн.; $\overline{C F}_{n p}$ - середньорічний приведений грошовий потік, грн., який визначається за формулою:

$$
\overline{C F}_{n p}=\frac{C F_{n p}}{T},
$$

де $T$ - кількість років, протягом яких очікується надходження грошових потоків.

Інший спосіб розрахунку періоду окупності інноваційного проєкту грунтується на постадійному відніманні від величини первісних інвестицій прогнозного річного грошового доходу у відповідному році. При цьому кожна наступна стадія розрахунку передбачає зменшення первісних інвестицій на величину доходу, враховану на попередній стадії розрахунку, тобто $P P=\min n$, при якому $\sum_{t=1}^{n} C F_{t} \geq I C$. Для останнього періоду можна визначити кількість місяців, протягом яких інвестиції повністю окупляться. 
Принции оцінювання - порівняння ефекту від застосування інноваиій $і$ витрат на їх розробку, виробництво та споживання.

Розрахунок відносної економічної ефективності капіталовкладень (при-ведених витрат).

Критерій мінімуму приведених витрат доцільно застосовувати у випад-ках, коли порівнюються варіанти, за яких не потрібна оцінка загальної ефективності інвестицій. Приведені витрати доцільно розраховувати, якщо $€$ кілька альтернативних варіантів інновації поліпшувального характеру або є базовий і новий варіант, тобто проєктом передбачено вдосконалення технологічного процесу, технічних засобів, економія ресурсів, оптимізація режимів виробничого процесу тощо. Критерієм вибору кращого варіанту є мінімум приведених витрат. Якщо порівняння здійснюється для базового і нового процесу, то можна розрахувати і економічний ефект від упровадження інновації, який буде дорівнювати різниці приведених витрат за базовим виробничим процесом і новим.

Показник приведених витрат розраховується за формулою:

$$
B_{i}=C_{i}+\mathrm{S}_{H} \cdot K_{i} \rightarrow \min ,
$$

де $C_{i}$ - поточні (експлуатаційні) витрати з розрахунку на одиницю продукції (собівартість тощо) за $i$-м варіантом, грн.; $K_{i}-$ питомі капіталовкладення за $i$-м варіантом (приймаються у випадку відсутності кошторису на проведення проектних заходів), грн.; $\mathrm{S}_{н}-$ нормативний коефіцієнт економічної ефективності капіталовкладень, част. од.

Термін окупності додаткових капіталовкладень розраховується за формулою:

$$
T=\frac{K_{1}-K_{2}}{C_{2}-C_{1}},
$$

де $K_{1}, K_{2}$ - питомі капіталовкладення за варіантами, що порівнюються, грн.; $C_{1}, C_{2}$ - витрати на виробництво річного обсягу продукції за відповідними варіантами, грн.

Розрахунок ефекту від зниження собівартості / від зростання обсягу реалізації інноваційної продукиії.

Зміст розрахунку даного ефекту зводиться до визначення показників умовно-річної (прогнозованої) економії витрат, фактичної економії витрат та річного економічного ефекту.

Умовно-річна економія витрат оцінює величину прогнозованої економії від упровадження нововведень. Розраховується за формулою: 


$$
\Delta S=S_{w}+S_{m}+S_{c f}-C h_{c}-C h_{e q}-C h_{e n},
$$

де $S_{w}$ - економія заробітної плати, грн. (розраховується у разі використання прогресивного способу виконання робіт); $S_{m}-$ економія витрат матеріалів, грн. (розраховується у разі застосування іншого матеріалу, іншого способу обробки тощо); $S_{c f}$ - економія умовно-постійних витрат, грн. (розраховується у разі збільшення обсягу продукції із застосуванням інновації); $C h_{c}$ - зміна витрат на амортизацію обладнання, грн.; $C h_{e q}$ - зміна витрат на утримання та експлуатацію обладнання, грн.; $C h_{e n}$ - зміна витрат на електроенергію, грн.

Економія заробітної плати визначається за формулою:

$$
S_{w}=\left(P_{1}-P_{2}\right) \cdot\left(1+E_{x p}\right) \cdot\left(1+E_{s n}\right) \cdot \mathrm{Q}_{2},
$$

де $P_{1}, P_{2}$ - розцінки на операцію відповідно до та після впровадження нововведення, грн.; $E_{x p}, E_{s n}$ - додаткова заробітної плати та нарахування на заробітну плату відповідно, част. од.; $\mathrm{Q}_{2}-$ річний обсяг виробництва продукції після впровадження нововведення, од.

Економія витрат матеріалів визначається за формулою:

$$
S_{m}=\left(C m_{1} \cdot \mathrm{Pr}_{1}-C m_{2} \cdot \mathrm{Pr}_{2}\right) \cdot \mathrm{Q}_{2},
$$

де $\mathrm{Cm}_{1}, \mathrm{Cm}_{2}$ - норми витрат матеріалів на одиницю продукції відповідно до та після впровадження нововведення, од. виміру; $\operatorname{Pr}_{1}, \operatorname{Pr}_{2}$ - ціна одиниці матеріалу відповідно до та після впровадження нововведення, грн.

Економія умовно-постійних витрат визначається за формулою:

$$
S_{c f}=\left(B_{c f 1}-B_{c f 1} \cdot \frac{b}{\mathrm{q}}\right) \cdot Q_{2},
$$

де $B_{c f 1}-$ умовно-постійні витрати на одиницю продукції до впровадження нововведення, грн.; $\boldsymbol{\theta}$ - індекс зміни умовно-постійних витрат, част. од.; q - індекс зміни обсягу виробництва, част. од.

Додаткові експлуатаційні витрати можуть виникнути внаслідок збільшення вартості основних засобів, що задіяні в інноваційному процесі, збільшення витрат на електроенергію тощо.

Тоді, зміна витрат на амортизацію обладнання визначається за формулою:

$$
\mathrm{C} h_{c}=\left(K_{2}-K_{1}\right) \cdot \frac{\mathrm{Q}_{2}}{Q_{1}} \cdot H_{c},
$$

де $K_{1}, K_{2}$ - вартість основних засобів до і після впровадження нововведень, грн.; $H_{c}$ - норма амортизації основних засобів, част. од.; 
$Q_{1}$ - річний обсяг виробництва продукції до впровадження нововведення, од.

Зміна витрат на утримання та експлуатацію обладнання визначається за формулою:

$$
C h_{e q}=\left(K_{2}-K_{1}\right) \cdot \frac{\mathrm{Q}_{2}}{Q_{1}} \cdot H_{e q},
$$

де $H_{e q}$ - норма витрат на утримання та експлуатацію обладнання, част. од.

Зміна витрат на електроенергію визначається за формулою:

$$
C h_{e n}=\left(\text { Pow }_{2}-\text { Pow }_{1}\right) \cdot T_{w} \cdot K_{o p} \cdot P_{r e n},
$$

де Pow $_{1}$, Pow $_{2}$ - потужність встановленого електрообладнання відповідно до і після впровадження нововведення, Вт; $T_{w}-$ річний фонд робочого часу обладнання, год.; $K_{\text {ор }}$ - коефіцієнт завантаження обладнання, част. од.; $P_{r e n}-$ вартість однієї кВт/год. електроенергії, грн.

Фактична економія витрат приводить умовно - річну економію до періоду використання інновації в даному періоді. Розраховується за формулою:

$$
S_{a c t}=\frac{\Delta S \cdot n}{12}
$$

де $n$ - кількість місяців до кінця року з моменту впровадження нововведення.

Річний економічний ефект розраховується за формулою:

$$
S_{\text {ann }}=\Delta S-S_{u} \cdot \Delta K,
$$

де $\Delta K$ - додаткові капіталовкладення пов'язані з проведенням проєктних заходів, грн.

Запропонована методика може застосовуватися i для визначення ефективності інновацій, спрямованих на підвищення якості продукції. Як правило, це супроводжується зростанням виробничих витрат (за рахунок підвищення складності робіт, що виконуються, використання дорожчих матеріалів тощо). Однак поліпшення якості продукції збільшує її споживчу вартість, що підвищує попит на неї і дає змогу виробнику встановлювати вищу ціну. Розрахунок річного ефекту здійснюють аналогічно, хоча матиме місце не економія витрат, а їх збільшення, тому $\Delta S$ матиме від'ємне значення. 


\section{4. Висновки}

Проведене дослідження дозволяє відзначити зростання інтересу до впровадження інновацій з боку вітчизняних підприємств. У той же час питання щодо готовності підприємства до розробки та/або впровадження інновації потребують змістовного обгрунтування та економічного оцінювання їхньої ефективності.

Результати дослідження дозволили зробити наступні висновки:

1. Визначено, що концептуально інноваційний проєкт являє собою сукупність етапів щодо формування інноваційної ідеї й мети, маркетингових досліджень, структуризації проєкту, аналізу ризику і невизначеності, вибору варіанта реалізації проєкту. Основні наукові положення дослідження цього питання базуються на працях С. Бушуєва, В. Гейця, С. Ілляшенко, Н. Ілляшенко, Ф. Ярошенко.

2. Відзначено, що життєздатність інноваційного проєкту оцінюється шляхом проведення проєктного аналізу. Досліджено та обгрунтовано типологізацію аспектів проєктного аналізу, до складових якого слід віднести: комерційний аналіз, технічний аналіз, інституціональний аналіз, соціальний аналіз, екологічний аналіз, фінансовий аналіз та економічний аналіз. Зазначені аспекти детально вивчаються на фазі ініціалізації та відслідковуються протягом всього періоду життєвого циклу інноваційного проєкту.

3. Дослідження дозволили відзначити те, що оцінювання ефективності інновації повинно грунтуватися на основі розрахунку критеріїв ефективності інноваційного проєкту, а також порівняння ефекту від застосування інновацій і витрат на їх розробку, виробництво та споживання. Основні наукові положення дослідження інструментарію та методології оцінювання ефективності інновацій базуються на працях Н. Караван, В. Ляшенко, І. Топалової, Б. Шелегеди.

4. Запропоновано структурну схему та формалізовано методичні підходи щодо оцінювання ефективності інновації. Реалізація методичних підходів, що запропоновано в цьому дослідженні, може мати корисний ефект, що дозволить оптимізувати рівень витрат на розроблення, виробництво та споживання інновацій. 


\section{Список літератури:}

1. Геєць В.М. Інституційна обумовленість інноваційних процесів у промисловому розвитку України. Економіка України. 2014. № 12(637). С. 4-19.

2. Ляшенко В.І., Ковчуга Л.І. Рівень інноваційної діяльності промислових підприємств: методичний підхід до оцінки. Економіка промисловості. 2018. № 4(84). C. 87-99.

3. Топалова І.А. Комплексна оцінка інноваційної привабливості галузі промисловості в регіоні: методичний аспект. Вісник економічної науки Украйни. 2019. № 1. С. 137-140.

4. Шелегеда Б.Г., Костенко Н.В. Інноваційна активність: показники виміру. Вісник приазовського державного технічного університету. 2001. № 11. C. $316-320$.

5. Ілляшенко С.М., Ілляшенко Н.С. Перспективи і загрози четвертої промислової революції та їх урахування при виборі стратегії інноваційного зростання. Маркетинг і менеджмент інноваџій. 2016. № 1. С. 11-21.

6. Ярошенко Ф.А., Бушуев С.Д., Танака Х. Управление инновационными проектами и программами на основе системы знаний Р2М : монография. Київ : Саммит-Книга, 2012. 272 с.

7. Маркетинг. Менеджмент. Інновації : монографія / за ред. С.М. Ілляшенка. Суми : «Папірус», 2010. 623 с.

8. Сафронов С.О., Караван Н.А. Проектний аналіз: інвестиційний аспект: монографія. Дніпродзержинськ : ДДТУ, 2013. 188 с.

9. Податковий кодекс України від 02.12.2010 р. № 2755-VI (зі змінами та доповненнями, поточна редакція від 29.12.2019, підстава - 323-IX, 391-IX, 425-IX) / Верховна Рада України. URL: https://zakon.rada.gov.ua/laws/show/ 2755-17/page (дата звернення: 29.01.2020).

10. П(С)БО 7 «Основні засоби» від 27.04.2000 р. № 92, зареєст. в Міністерстві юстиції України 18.05.2000р. за № 288/4509 (зі змінами та доповненнями, поточна редакція від 29.10.2019, підстава - z1065-19) / Міністерство фінансів України. URL: http://zakon.rada.gov.ua/laws/show/z0288-00 (дата звернення: 28.01.2020).

\section{References:}

1. Heyets V.M. (2014). Instytutsiina obumovlenist innovatsiinykh protsesiv u promyslovomu rozvytku Ukrainy [Institutional conditionality of innovative processes in Ukraine's industrial development]. Economy of Ukraine, Vol. 637, no. 12, pp. 4-19. (in Ukrainian)

2. Lyashenko V.I., Kovchuga L.I. (2018). Riven innovatsiinoi diialnosti promyslovykh pidpryiemstv: metodychnyi pidkhid do otsinky [The level of innovation activity of industrial enterprises: a methodological approach to assessment]. Industrial Economics, vol. 84, no. 4, pp. 87-99. (in Ukrainian)

3. Топалова I.A. (2019). Kompleksna otsinka innovatsiinoi pryvablyvosti haluzi promyslovosti $\mathrm{v}$ rehioni: metodychnyi aspekt [Integrated assessment of innovative attractiveness of industry in the region: methodical aspect]. Bulletin of Economic Science of Ukraine, no. 1, pp. 210-216. (in Ukrainian) 
4. Shelegheda B.G., Kostenko N.V. (2001). Innovatsiina aktyvnist: prikaznyky vymiru [Innovative activity: measurement indicators]. Bulletin of Azov State Technical University, no. 11, pp. 316-320. (in Ukrainian)

5. Ilyashenko S.M., Ilyashenko N.S. (2016). Perspektyvy i zahrozy chetvertoi promyslovoi revoliutsii ta yikh urakhuvannia pry vybori stratehii innovatsiinoho zrostannia [Perspectives and threats of the fourth industrial revolution and their consideration when choosing the strategy of innovative growth]. Marketing and Innovation Management, no. 1, pp. 11-21. (in Ukrainian)

6. Yaroshenko F.A., Bushuev S.D., Tanaka H. (2012). Upravlenie innovatsionnyimi proektami i programmami na osnove sistemyi znaniy R2M: monografiya [Innovative projects and programs management based on the P2M knowledge system: monograph]. Kyiv: Summit Book. (in Russian)

7. Illyashenko S.M. (ed.) (2010). Marketynh. Menedzhment. Innovatsii: monohrafiia [Marketynh. Menedzhment. Innovatsii: monohrafiia [Marketing. Management. Innovation: monograph]. Sumy: Papyrus. (in Ukrainian)

8. Safronov S.O., Caravan N.A. (2013). Project analysis: investytsiinyi aspect: monohrafiia [Project analysis: investment aspect: monograph]. Dniprodzerzhinsk: DSTU. (in Ukrainian)

9. Podatkovyi kodeks Ukrainy vid 02.12.2010 r. \# 2755-VI (zi zminamy ta dopovnenniamy, potochna redaktsiia vid 29.12.2019, pidstava - 323-IX, 391-IX, 425IX) / Verkhovna Rada Ukrainy [Tax code of Ukraine dated 02.12.2010 \# 2755-VI (withamendmentsandsupplements, currentversiondated29.12.2019, ground-323-IX, 391-IX, 425-IX) / Verkhovna Rada of Ukraine]. URL: https://zakon.rada.gov.ua/ laws/show/2755-17/page (accessed 29 January 2020).

10. P(S)BO 7 «Osnovni zasoby» vid 27.04.2000 r. \# 92, zareiest. v Ministerstvi yustytsii Ukrainy 18.05 .2000 r. za \# 288/4509 (zi zminamy ta dopovnenniamy, potochna redaktsiia vid 29.10.2019, pidstava - z1065-19) / Ministerstvo finansiv Ukrainy [P (C) BO 7 «Fixed assets» dated 27.04.2000, № 92, reg. at the Ministry of Justice of Ukraine on May 18, 2000 No. 288/4509 (with amendments and supplements, current version dated October 29, 2019, ground - z1065-19) / Ministry of Finance of Ukraine]. URL: http://zakon.rada.gov.ua/laws/show/z0288-00 (accessed 28 January 2020). 